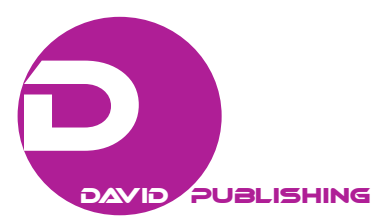

\title{
Secondary Education in Argentina: A Winding Road
}

\author{
Ximena Valente Hervier, Virginia Scotta, Susana Marchisio \\ National University of Rosario, Rosario, Argentina \\ Ricardo Martín Fernández \\ National Technological University, San Nicolás, Argentina
}

\begin{abstract}
This paper is aimed at exploring the state of the secondary education in Argentina, with special emphasis on the different changes and approaches of inclusive education public policies introduced in the last years. Argentina has been experiencing profound changes in relation to the population groups with access to the different educational levels, presenting painful differences in the quality and effectiveness of education given in different population and geographic sectors. Secondary education in Argentina is currently the educational level on which all eyes are focused. On the one hand, due to the progressive obligatoriness, but to a greater extent a large number of secondary school age population are effectively excluded from the possibility of exercising the right to quality education. The paper tries to examine, through an analysis of the strengths, weaknesses, opportunities, and threats of the Argentinian educational system, what are the critical points of inflection where to incorporate elements of innovation to achieve better quality and inclusion standards in a country marked by deep levels of inequality in the access and quality of education in its different population groups. The research has been conducted through a descriptive methodology, using quantitative and qualitative analysis of primary and secondary sources. It is set on a bibliographical review based on reports and studies of recent publications, coming from official, national, and international public institutions. The paper aims to be a first step in a diagnostic analysis of Argentinian education, but in a comparative manner, contrasting indicators and local indexes with international and regional trends in the subject. The main results point out that a deep transformation of the secondary school is needed, in such a way as to respond to the many signs of inequality, fragmentation and poor quality of the most vulnerable population groups.
\end{abstract}

Keywords: secondary education, public policies, pedagogic innovation, inclusion

\section{The State of Secondary Education in Argentina as a Research Problem}

Secondary education is currently in Argentina, as well as in all the countries in the region, the educational level on which all the eyes are focused. On the one hand, due to the progressive obligatory nature of the level

Ximena Valente Hervier, bachelor in Political Science, master of Philosophy in Conflict Resolution, Faculty of Exact Sciences, Engineering and Surveying, National University of Rosario, Rosario, Argentina.

Virginia Scotta, bachelor in Political Science, master in Local Economic Development, Faculty of Exact Sciences, Engineering and Surveying, National University of Rosario, Rosario, Argentina.

Susana Marchisio, Ph.D. in Industrial Engineering, Faculty of Exact Sciences, Engineering and Surveying, National University of Rosario, Rosario, Argentina.

Ricardo Martín Fernández, senior electronic engineer, Department of Electronic Engineering, Regional Faculty of San Nicolás, National Technological University, San Nicolás, Argentina.

Correspondence concerning this article should be addressed to Susana Marchisio, Physics Department. Faculty of Exact Sciences, Engineering and Surveying, National University of Rosario, Avda. Pellegrini 250, (2000) Rosario, Argentina. 
after the enactment of Law No. 26.206, but to a greater extent a large number of the population of school age who are excluded in fact from the real possibility of exercising that right.

If we understand education as "(...) the political action that allows to transmit cultural capital through the generations, to distribute the inheritance, designating the social collective as heir” (Viscaíno, 2013, p. 1), this process of transmission is intrinsic to our structures of organizing social life. This process of transmission implies processes of permanent learning that define how subjects as social beings adopt certain positions, values, and behaviors. For this reason, they are not only a content transmission belt, but are also shaped as complex social processes with a clear political, institutional construction and subjective elaboration implications (Viscaíno, 2013). For this reason, the educational system results from a historical, social, and ideological process that is formulated in a given time and space, combining traditions and innovations: tradition allows to give continuity to past ideas and experiences, and innovation refers to the search for answers to new formative demands of society in complex times.

Historically, secondary school as an institution goes back to the European continent in the sixteenth and seventeenth centuries, as a process of systematization of courses of preparatory and humanistic (encyclopedic) content for access to the university, access that was reserved for young male members of wealthy elites (Ferreyra, 2012, p. 3).

Since the nineteenth century phenomena such as population growth, rapid industrialization, transcontinental migratory movements, among others, motivated new social sectors to access secondary education, developing schools of instruction with a popular character. This type of offer was motivated by the growing demand for training for work that, associated with the Great Industrial Revolution, gave rise to apprenticeship schools or arts and crafts schools, providing professional, practical, and manual training, and enabling its graduates to insert themselves as workers in the industry and not for the path towards university.

In the second half of the twentieth century and as a result of great changes in the social, political, economic, cultural, and technological spheres, middle school became broader, opening its doors to a highly heterogeneous population. In most states, compulsory secondary education is being extended to at least one basic cycle, incorporating two major functions for itself: delivering solid general education to provide a broad base of cultural sustenance for its population, as well as training for continuing higher education and/or the productive life. It is in this context that secondary school is crossed by an expansive process that manifests itself in the massification of its enrollment, in the normative mandates of extension of the obligatoriness and by the regulatory presence of the state actors (Ferreyra, 2012). This situation occurs both in the developed world (where enrollment reaches $86 \%$ of the young and adolescent population) as well as in the developing world (with rates of around $68 \%$ of coverage).

\section{Research Methods}

The present research is dedicated to exploring the state of secondary education in Argentina, taking as a starting point the main reports, publications, and scientific meetings that have been dealing with this subject in the last 10 years, with special emphasis on the different approaches of public policies of inclusive education (Rico, 2010) and with universal vocation implemented in the last years. The research has been conducted through a descriptive methodology, using quantitative and qualitative data of primary and secondary sources. It is set on a bibliographical review based on reports and studies of recent publication coming from official national and international public institutions. 
In the following section, the traits that have historically characterized secondary education in Argentina are highlighted. They arise as a product of the historical review, based on the qualitative analysis of representative official studies on secondary education in Latin America and Argentina. In the next section the main sources of statistical data are revised. Next, the analysis of the results allows for the elaboration of a first diagnosis of Argentine secondary education. At last, some lines of action that emerge as necessary to be carried out under a deep transformation of secondary education Argentina are discussed.

\section{Contributions From the Qualitative Educational Research}

Secondary school in Latin American has been systematized early in time, being massified after the 1950s and having adopted the logic of the segmentation and performance of a certain institutional model (Briscioli, 2012). Although progress has been made in the last 10 years, the situation of education in Latin America, a region with the highest income inequality in the world, remains a deficit. Despite the enormous progress made in the last two decades, the situation of education in Latin America is not yet satisfactory: pre-school education is still very minor, primary school completion rate is low, secondary education has insufficient figures, quality of education is still deficient, inequality is still a big issue (gender is more subdued, the socioeconomic and territorial gap stands out), the percentage of adults without literacy is very high, and a high percentage of literate young people and adults lack vocational training to enable them to gain access to a minimally qualified job and to maintain it as a stable source of income (Vélaz de Medrano Ureta, 2005, p. 8).

A significant number of countries in the region have set themselves the goal of compulsory secondary education, facing complex scenarios that require new and innovative strategies. In some of these countries, there will be the first generation of adolescents with real possibilities of access to this level of education.

In the context of Latin America, the secondary education in Argentina has been, since its inception, the most complex and difficult educational cycle in its conceptual precision as an educational segment of the national system (Ferreyra, 2012). After the 1930s and in a social context marked by the expansion of industrialization by import substitution, the social function of the school was radically changed: its objectives were broadened, incorporating also the preparation for work. And it is in this context that the diploma of secondary education began to give sustenance to certain phenomena of upward social mobility of large population groups (Almandoz, 2010).

As for the regulation of the level, it is important to note that the most recent research on secondary school shows the void existing in the legislation, having only developed partial rules to regulate certain specific aspects, a vacuum that goes back to the National Constitution, which makes only a diffuse mention of high school. In this way, the expansion of this educational level is developed without an integral legislation that gives organicity to the different offers, modalities, and orientations (Ferreyra, 2012).

Secondary education in Argentina has taken an unusual role since the 1980s, in the context of debates on the democratization of education systems, with a special emphasis on the necessary democratization of access to schooling and the necessary quality of the educational service to obtain the permanence and the graduation of students. The main characteristics of the evolution of the middle level have made secondary school the focus of education policy, generating various proposals for reform, which for a long time could not reach the necessary consensus for its implementation (Aguerrondo, 2009). At this stage, small changes were made to its contents, methodologies, and evaluation methods, and certain pilot experiences were developed. But it was not until the 1990s that a comprehensive reform was implemented (Aguerrondo, 2009). 
However, these changes seem to have not penetrated deeply into the very structure of secondary school, which does not yet seem ready to efficiently face the current massification and to effectively receive a population with characteristics and expectations very different from that of the sectors for which it was thought in previous periods. Since 2006, Argentina has approved a normative framework that restructures the educational system at the national level. All these provisions have generated strong structural changes and redefinitions of school supply (in terms of duration, cycles, institutional definition, etc.), but in spite of these intense processes, the institutional pattern of the secondary school proposal has remained largely unchanged.

While recognizing the need to maintain and strengthen certain programs focused on the principle of equity, in order to specifically address large conglomerates in vulnerable situations, the transversal axis that guides this new stage is that of achieving universality in secondary school as a way to materialize educational inclusion (Castro, 2011). It is worth noting the incorporation made by Law No. 26.206 of compulsory schooling at the secondary level. In this sense, since 2014, school compulsory education has spread throughout the country from the age of four to the completion of the secondary level.

The compulsory nature of secondary education in Argentina is set in a context of great inequalities, marked by the presence or absence of schools or professors graduated in different junctures, as well as by the existence of highly differentiated circuits in relation to the educational quality and assimilated learning, thus delimiting multiple scenarios of great complexity (Cappellacci, 2009). From one side, the compulsory character of secondary school must be intrinsically linked to the expansion of the educational offer throughout the territory, which is subsumed in very different spectra between urban and rural spaces, and determined by an uneven school infrastructure. In this context, it is essential to ensure the objective conditions for all adolescents to have concrete possibilities to access stay and finish school with valid and meaningful learning.

From a historical perspective it can be said that access to secondary education in Argentina has been growing. This is reflected in the increase of enrollment rates, showing that the number of adolescents and youngsters from sectors hitherto excluded has increased, and the average number of years of schooling has increased. However, this sustained increase in access has not been able to solve the historical problems of secondary school. On the one hand, the problem of repetition, which continues to be very high, and as a result of repeated repetitions, school drop-out is high in subsequent years. And in terms of graduation rates, depending much on the socioeconomic sector from which the student comes, the rates also vary markedly.

In order to be able to advance in a real diagnosis of the state of the education situation in Argentina, it is necessary to specify its evaluation tools and the results obtained.

\section{Contributions From the Evaluation Tools}

National Assessment Operations have been systematically carried out in the 24 educational jurisdictions since 1993, being conducted by the Educational Quality Assessment Area, at the National Directorate of Information and Evaluation of Educational Quality of the Ministry of Education of Argentina. These assessments were carried out in the last years of each educational level in the following areas: Spanish Language, Mathematics, Natural Sciences, and Social Sciences. Mainly, these evaluations reveal, the existence of inequalities in the educational quality according to jurisdictions.

The overall results of UNICEF's assessment of learning in its Report "About compulsory secondary school in Argentina” can be summarized as follows (UNICEF, October 2012, pp. 51-52):

(1) Increase in enrollment in the age group between 14 and 17 years of age. 
(2) The same rate is falling by 40.7 points in the range $12-17$ years.

(3) Relative increase in enrollment in 17-year-old.

(4) Significant differences between jurisdictions in terms of schooling.

(5) Adolescents and young people who by their age should be in school and are not reaching $12 \%$ of the total. However, there is an increase in enrollment at the secondary level, which can be expected to reverse the situation.

(6) Increased repetition in all study years, with peaks of concentration in grades 8 and 9.

(7) Increased drop out of schooling, especially in grades 8 and 9.

(8) Increase in the number of over-age students.

(9) Promotion decreases in all grades (noting that the last year with available information is 2009).

(10) Increase in the total number of teaching positions, especially in the state sector.

(11) $48 \%$ of educational units should have institutional changes to fit the organization of the secondary level of their corresponding jurisdiction.

(12) Improvement in Spanish Language and Mathematics performance in the last years of high school.

Another great instrument of measurement of the effectiveness of the Argentinian education arises through the Program for International Student Assessment (PISA). This program is a tri-annual test conducted by the Organization for Economic Co-operation and Development (OECD) to evaluate the educational systems of its member states and all other states that wish to participate in it. This assessment is made to 15-year-old students regardless of the year they are in school. They work with this population because they are young people who are about to start higher education, or are in many countries about to be integrated into working life.

Although the first evaluation of the PISA program was carried out in 2000, as the publication of its results generated a lot of interest in other non-OECD countries, a decision was made to organize what was called PISA PLUS, an additional collection of data in the year 2001, in which Argentina participated. Analyzing the relative position of Argentina in the successive evaluations of 2001, 2006, 2009, and 2012, the Civil Association for Educational Improvement in Argentina recognizes the following important facts to summarize the country's trajectory in the program (Ganimian, 2012):

(1) Argentina has been ranked among the eight worst participating countries, while the level of the Autonomous City of Buenos Aires was comparable to that of the Latin American countries with the highest scores, evidencing the great inequity in the distribution of educational quality at the national level. However, both systems were very far from the countries with the highest rankings within the program.

(2) Argentina has not registered any improvement in any subject since it began to participate in the evaluations, despite having been participating in more than a decade. Comparatively, several Latin American countries have been able to improve significantly, especially in the cases of Brazil, Chile, and Peru.

(3) A worrying percentage of Argentine students did not reach the minimum levels of learning in Reading, Mathematics, and Science. Two-thirds of the students scored at the lowest levels in Math, and one in two in Reading and Science.

(4) Less than $1 \%$ of students in Argentina managed to achieve excellence in all subjects - this percentage is even lower in Math and Reading. The Autonomous City of Buenos Aires registered a higher rate in all subjects, being the highest in Latin America, but also very low according to international standards.

(5) Argentina had one of the smallest gender gaps in Mathematics, but one of the highest in Reading, with males performing better in Math and women in Reading. There were no gaps in Science. 
(6) Rural students performed a grade level behind in comparison with their peers living in an urban context in Mathematics. Argentina was one of the few countries that registered gaps between students from rural and urban environments. It can be said that gaps by socio-economic level are the widest in the world. Argentina performs well below other countries with similar levels of income or investment in education. In Mathematics and Science, Argentina was the worst performing country for its income level. And while Argentina has the highest per capita investment among the eight Latin American countries participating in the program, its performance is among the lowest in the region.

In the 2015 edition, eight Latin American countries participated, including Argentina, and these eight countries are in the third of inferior performance. Argentina ranks 58 in Science, 59 in Mathematics, and 61 in Reading, out of 65 countries around the world. The Civil Association for the Improvement of Education in Argentina, through its Educar 2050 Project, identifies some key findings in the analysis of data provided by the PISA program (Ganimian, 2014):

(1) Salaries of secondary school teachers in Argentina are among the lowest in PISA participating countries. In this case, higher wages are related to better performance.

(2) The Argentine school year is shorter than that of most PISA participating countries, but there is no relationship between the length of the school calendar and performance.

(3) About half of Argentina's high school principals report school infrastructure problems. Education systems with better school infrastructure perform better, but this can happen because they tend to be more developed.

(4) Between one-third and half of the 15-year-old Argentines evaluated attend school with lack of educational resources, according to surveys done to their principals.

(5) Argentina is among the countries that evaluate their schools the least and use less the results of evaluations, according to the principals themselves. This is very worrying, since those systems that best use their evaluations seems to obtain improvements in their results more quickly.

(6) Argentine high school principals report problems with alcohol and drug abuse, violence and disorder in their classes. However, there is no clear relationship between performance and the rate at which the PISA program computes all these factors.

(7) A high percentage of Argentine secondary school principals report problems with teacher absenteeism and delays in their schedules. These practices are negatively related to performance.

(8) The vast majority of 15-year-old are grouped in school according to their Math skills. This practice is negatively related to performance.

(9) Argentine private schools perform better, even when compared to public schools with students of similar socioeconomic status.

(10) The 15-year-old Argentine students who attended the initial level for more than a year have better performance than those who did not. This advantage is maintained when compared to students of similar socioeconomic level.

(11) Argentina has the highest student absenteeism rate in all participating countries in PISA. More than half of the high school students evaluated admitted to having missed class and being late, both of which are contrary to performance.

(12) A high percentage of Argentine students say they have not heard of basic concepts in Mathematics, such as probability, vectors, or equations. Furthermore, there are several Argentine students who say they do not apply Mathematics to solve real-life problems. This is a key point to analyze the performance of Argentine 
students, the little "put into utility" of the contents supposedly learned in the school in their daily lives, failure that drags on and gets worse in the upper cycle, generating high rates of abandonment and increasingly low levels of understanding and apprehension of competences and abilities at the university.

\section{Rethinking Secondary Education in Argentina}

In the following pages, we aim at addressing some issues that we consider central to rethinking secondary education in Argentina as a central passage in the education of our citizens, either as a bridge between the school and the labor market, but fundamentally as the golden thread between school and university.

\section{The New Subjectivities}

A first topic to be analyzed is whether current school can deliver to what literature calls the new subjectivities. An important part of adolescents and young people who do not have access to high school, or who do not complete it, live in contexts in which their most fundamental rights are violated on a daily basis. In this context, school can't be the only space of response to their vulnerable schooling. That situation demands the implementation of adequate and precise multisector coordination mechanisms to address the situations that negatively determine the educational trajectory of those vulnerable adolescents and young people.

Difficulties of the secondary school academic systems to incorporate new social groups generate, in many cases, the creation of differentiated circuits in educational quality. In this way, school graduates belonging to the same curriculum coexist with similar titles in the formal, but with widely dissimilar learned content. However, it can be assumed that the new social sectors incorporated at the secondary level have done so, in many cases, in educational circuits of lower quality and with worse conditions of infrastructure and equipment (Kessler, 2002). It should be borne in mind in this equation that the sectors located in the first quintiles, that is, which have the lowest income, attend mostly state-run establishments, while in the higher income sector six out of 10 young people attend private schools, with abysmal differences regarding school infrastructure and the effectiveness of knowledge acquisition in both regimes (Kisilevsky, 2002).

As the official statistics of the Ministry of Education show, while $80 \%$ of the students with greater economic resources graduate in Argentine, less than $40 \%$ of the young people with lower resources manage to graduate at the same level. To this gloomy picture, we must add that more than $9 \%$ of adolescents coming from the lowest income households have not completed primary school (Fundación Cimientos, 2011).

Another serious problem is the number of over-age students, that is, students who are out of phase according to the criteria that link age to year or level in which they are expected to attend school. According to López (2008), around 6\% of adolescents between 15 and 17 years of age are four years delayed in comparison to their age corresponding level (López, 2008, p. 80).

\section{The School Format}

A second major challenge is in relation to the school format, which is those foundations in which the knot of the modern school rests and that is particularly difficult to modify: the graduation of each course, the age separation of the students, the organization of the curricula based on different disciplines, and the promotion with the complete course approved. These conditions were designed for the students who attended the classrooms during the gestation period of the secondary school project, out-of-date conditions that are far from those present in large conglomerates of students currently attending school. Within the school format, two issues are of special relevance: the curricula structuring and the teachers' education (Niemi, 2009). 


\section{The Curricula Structuring}

Regarding the curricular question, despite numerous initiatives to reform it (the most recent attempt being promoted by the Federal Education Law, now repealed), no substantive changes have been made so far. In the debate around this question, two hypotheses are formed, which nourish educational literature profusely, as Terigi (2012, p. 55) well explains. On the one hand, the hypothesis is that the pressing situation of secondary education is related to the same old problems, but enhanced by the current massification. In this sense, here count the usual problems of the school: its great encyclopedic approach, or the arbitrariness of its academic regime. The second hypothesis focuses on the new problems, which the school has never experienced before. The abuse of prohibited substances, violence in the school environment, the social relevance of secondary school are of particular relevance. Obviously, the combination of the first and second hypotheses gives an account of the explosive cocktail in which secondary school has become, a cross-linking of the old problems that still cannot be solved today, together with new problems that had not arisen before. Specifically, around the school curriculum, this amalgam of new and old problems is presented, on the one hand, by an excess of information in the programs, and on the other, a certain anachronism of the contents vis-à-vis the expectations and motivations of the students of the new Millennium. New questions are rising around the need to assume certain cultural codifications for which the Nineteenth Century School was not prepared. The central argument of the new movement is the need to incorporate new knowledge that was not part of the cultural perspective of the nineteenth century, when the classical curriculum was developed. This knowledge is part of a pool of "new disciplines" as is the case of technologies, the world of image, and the concern for the sustainability of the environment, among others.

Now, how is it possible to implement this change? Here is the key to the Gordian knot. Terigi (2012, p. 64) advances in what the author considers three key axes to think about a possible curricular reform in the Argentinian high school. On the one hand, it is necessary to think about having a strongly classified curriculum, on the other, it is necessary to have specialized teachers training (Tenti Fanfani, 2012, p. 65). In the current high school curriculum, which is heavily classified, the vast majority of content is transmitted in closed curricular units (subjects), with well-defined limits between one another, which already show a clear anachronism with overlap and juxtaposition of knowledge of the digital age. This leads to the second problem, the inexorable link between specialized curriculum and teacher training.

\section{The Teachers' Education}

At the international level, the criterion of focusing attention on the teaching level is being imposed as a way to improve students' performance. While it is absurd to pretend that the only reason behind student performance is the educator's performance, agencies like the OECD are emphasizing the importance of measurement efforts in this regard. It is important to remember that in Argentina there is a mandatory annual evaluation, but it has been experiencing complications in its implementation dynamics. The evaluation is in charge of the principal of each institution, a situation that implies the high subjectivity of each principal in terms of their willingness not to damage the reputation of their institution. The available data are often sectorized, poorly surveyed or simply inaccurate, thus making it difficult to systematize the information to achieve a finished diagnosis. There is also a great deal of concern about the level of education of teachers: there is a significant number of secondary school teachers who do not have the appropriate academic qualifications, nor is there sufficient and up-to-date pedagogical training, being easy victims of demotivation due to the 
increasing complexity of their task, due to the lack of incentives and the poor social status of their profession (Niemi, 2009). Given this scenario, instead of attempting to undertake comprehensive reforms that are presented as pharaonic tasks due to their size and efforts involved, the need arises to face small gradual and progressive changes to a curriculum that is already obsolete. In this sense, and following Terigi's (2012) reasoning, four major progressive changes can be identified in the secondary school curriculum:

(1) Gradually introduce (a few) new components into the curriculum, such as "Education for Citizenship", "Integral Sexual Education”, or "Environmental Sustainability”.

(2) Improve the relevance of the curriculum content, improving the interconnection between different knowledge spheres.

(3) Generation of institutional resolution alternatives with central directionality, generating from within the school the obligatory debate on curricular reform.

(4) Changes in the pedagogical design of schooling, bridging the use of New Information and Communication Technologies (ICTs) to connect the possible content of the curriculum with the contemporary culture of young people and their sense of belonging and validation of knowledge (Marchesi, 2010).

\section{Conclusion}

The main results regarding trends in secondary education can be summarized in four main points, according to the UNICEF report on the state of secondary education in Argentina (Binstock, 2005):

(1) Significant progress has been made in the coverage levels of the system, which has a direct consequence on the more significant increase in the presence of economically disadvantaged sectors in the classrooms;

(2) There is a relative stability and persistence in the levels of school dropout (approximately $30 \%$ of the enrollments of the level);

(3) Comparatively, female students record more advances and educational achievements than their male counterparts;

(4) A slight anticipation of the time at which school drop-out occurs can be detected if early warning tools are put in place properly.

Among the main current problems of secondary education, we can summarize, using the useful systematization of Vélaz Medrano de Ureta (2005, p. 41), the following points:

(1) The curriculum is not sufficiently up-to-date (by not yet incorporating cross-cutting knowledge, such as civic education, health education, technology, etc.).

(2) Pedagogical methods and textbooks are inadequate to achieve the curricular objectives, being very disconnected from the experiential experience, are little contextualized.

(3) Schools are poorly equipped and their organization does not meet the needs of vulnerable groups (low inclusiveness).

(4) Teachers are often insufficient to meet the student population needs, and often lack the necessary curricular and pedagogical training (Tiramonti, 2007).

Certainly, school, by itself, cannot and will not be able to face the current challenges. But what is possible is to rethink the school as a platform for greater equity (Cabrol, 2014). There are many innovative experiences in the world that go in that direction (García Ruiz, 2010; Pallarès Piquer, 2013; Scott, 2013; CEPAL/UNESCO, 2005). 
The PISA reports (2000; 2003) confirm that on many occasions (too many) school does not mitigate the influence of the family environment, but reinforces it (Vélaz de Medrano Ureta, 2005, p. 75).

A deep transformation of the secondary school is needed, so as to meet the diverse expectations of the different schooling groups, with a different organization of the curriculum and the institutional life (Tiramonti, 2007), in such a way as to respond to current requirements of life, and to the many signs of inequality, fragmentation and poor quality of the most vulnerable groups (Nino, 2011). This secondary school is the one that no longer guarantees the successful entry to labor market (García de Fanelli, 2005), but must prepare its students for insertion in the structures of post-secondary education that gives them the necessary tools to ensure a future social and labor insertion, either through technical professional studies or university studies (Llisterri, 2014). As it was reviewed in the previous pages, small changes can be introduced in school practice, in a way that it helps to facilitate the transition to a more flexible school in its contents and in its regimes. We should think of a school with a curriculum more anchored in the needs of adult life, based on knowledge that gives concrete answers to the demands of everyday life. A curriculum that teaches students to think, to understand, to be able to discern between the great information mess to which they are exposed daily, and that teaches them to communicate, to solve problems in a collaborative way, and to use their own resources (Tiramonti, 2007). Likewise, we must project a school whose teachers are integrated into the institution not as random pieces, in order to occupy a grid in the knowledge board to comply with the minimum mandatory contents, but teachers who can involve their knowledge from participatory and collaborative approaches in spaces that go beyond the traditional classroom (Marchesi, 2010). But we also have to prepare teachers for this pharaonic task, teachers who are socially recognized in their work for their years of dedication and training for the most needed profession in the world, and have the necessary material and symbolic means to fulfill its mission. Those changes, in order to take effect, must be done at the root, and for this, beyond supporting the movement establishing the most appropriate normative framework to promote it, it is necessary to focus on the micro politics of educational institutions, that is, changes in the structure from the work of key school actors, especially the teachers.

The teacher is the head of the classroom and must rewrite the curriculum imposed as a daily task. Although initial teacher training is central, it should be accompanied by specific support to work within the school, generating work cultures, team actions, and indigenous intellectual tools to consolidate change. And that is about change, a change that must necessarily be gradual, apprehended by its own protagonists. The key, then, is how to generate small successive changes that function as building blocks for a colossal-sized work.

\section{References}

Aguerrondo, I. (2009). Niveles o ciclos. El reto de la articulación. Revista Internacional Magisterio, 38. Almandoz, M. R. (2010). Educación y Trabajo: Articulaciones y políticas. Buenos Aires: IIPE-UNESCO.

Binstock, G. (2005). Carreras truncadas. El abandono escolar en el nivel medio en la Argentina. Buenos Aires: UNICEF.

Briscioli, B. (2012). La escolarización secundaria obligatoria. Dos estudios sobre políticas destinadas al reingreso de adolescentes

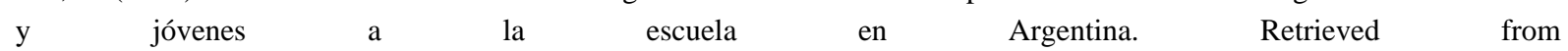
http://www.ungs.edu.ar/ms_idh/wp-content/uploads/2012/10/Briscioli-Toscano-CLACSO.pdf

Cabrol, M. (2014). ¡Vamos Argentina! Hacia un país de graduados.Cómo universalizar la educación secundaria. Washington, D.C.: BID.

Cappellacci, F. J. (2009). El proceso de democratización del nivel medio en el sistema educativo argentino. Espacios de Crítica y Producción, 88-95. 
Castro, A. (2011, Noviembre). La inclusión educativa en la escuela secundaria. Aportes desde la investigación. XI Congreso Nacional de Investigación Educativa. Nuevo León, México.

CEPAL/UNESCO. (2005). Invertir mejor para invertir más. Financiamiento y gestión de la educación en América Latina y el Caribe. Santiago de Chile.

Ferreyra, H. A. (2012). Aproximaciones a la educación secundaria en la Argentina (2000-2010). Córdoba: Comunic-Arte.

Ferreyra, H. A. (2012). Configuración de la Educación Secundaria. El caso de algunos países del mundo y de América Latina desde una perspectiva comparada. Revista Latinoamericana de Educación Comparada, 3(3), 64-70.

Fundación Cimientos. (2011). La educación argentina en números. Buenos Aires: Educación Cimientos.

Ganimian, A. (2012). No logramos mejorar: Informe sobre el desempeño de Argentina en el Programa para la Evaluación Internacional de Alumnos (PISA). Buenos Aires: Proyecto Educar 2050.

Ganimian, A. (2014). Pistas para mejorar. ¿Qué hicieron los países, escuelas y estudiantes con mejor desempeño en el Programa para la Evaluación Internacional de Alumnos (PISA) 2012? Buenos Aires: Proyecto Educar 2050.

García de Fanelli, A. M. (2005). Acceso, abandono y graduación en la educación superior argentina. Buenos Aires: SITEAL.

García Ruiz, M. J. (2010). Estudio comparativo de la educación: Finlandia y Comunidad de Madrid. Análisis y recomendaciones. Madrid: Comunidad de Madrid.

Kessler, G. (2002). La experiencia escolar fragmentada. Estudiantes y docentes en la escuela media en Buenos Aires. Buenos Aires.: IIPE-UNESCO.

Kisilevsky, M. (2002). Dos estudios sobre el acceso a la educación superior en la Argentina. Buenos Aires: IIPE-UNESCO.

Llisterri, J. J. (2014). Educación técnica y formación profesional en América Latina. El reto de la productividad. CAF.

López, N. (2004). Educación media de calidad para todos, un difícil desafío para los países de América Latina. Siteal. Retrieved enero 2015, from http://www.siteal.iipe-oei.org/sites/default/files/boletin_06.pdf

López, N. E. (2008). The school and teenagers. Social and educational trends in Latin America. SITEAL.OEI. IPPE.UNESCO.

Marchesi, Á. (2010). Metas educativas 2021: Propuestas iberoamericanas y análisis nacional. Buenos Aires: Santillana.

Niemi, H. (2009). El currículo en la formación del profesorado de educación secundaria. Revista de Educación, 73-202.

Nino, E. (2011). La desigualdad en el acceso a la educación universitaria argentina. Lecciones y Ensayos, 351-366.

Pallarès Piquer, M. (2013). El sistema educativo finlandés como base de la formación del profesorado. Actitudes de los equipos docentes de secundaria hacia un modelo educativo exitoso. Revista de Investigación en Educación, 2(11), 158-171.

Rico, A. P. (2010). Políticas de educación inclusiva en América Latina. Revista Educación Inclusiva, 3(2), 125-142.

Scott, P. (2013). La educación matemática en Finlandia: Un camino seguro para otros países o una anomalía. I Congreso de Educación Matemática de América Central y el Caribe. Santo Domingo.

Tenti Fanfani, E. (2012). La escolarización de los adolescentes: Desafíos culturales, pedagógicos y de política educativa. Buenos Aires: IIPE-UNESCO.

Terigi, F (2012). Sobre la Cuestión Curricular en la Educación Secundaria.enTentiFanfani, E. (Comp.) (2012). La escolarización de los adolescentes: Desafíos culturales, pedagógicos y de política educativa.Buenos Aires: IIPE-UNESCO, 55-77.

Tiramonti, G. E. (2007). New school formats to promote educational inclusion: A case study-The Argentina experience. Buenos Aires.

UNICEF. (2010). Educación Secundaria. Derecho, inclusión y desarrollo. Desafío para la educación de los adolescentes. Buenos Aires: Unicef.

UNICEF. (October 2012). About the compulsory in the Argentine secondary school. National political analysis. Buenos Aires.

Vélaz de Medrano Ureta, C. (2005). Los retos de la educación básica en América Latina. Madrid: CEALCI.

Viscaíno, A. M. (2013). Educación secundaria y procesos de filiación simbólica en jóvenes que dejan de asistir a la escuela. KAIROS, 1-14. 